\title{
Clinical Significance of Tumour CD44v and MIST1 Expression in Patients With Non-small-cell Lung Cancer
}

\author{
TAKUYA NAGASHIMA ${ }^{1,2}$, TAKASHI OSHIMA ${ }^{3}$, YUKIHIKO HIROSHIMA ${ }^{4}$, \\ TOMOYUKI YOKOSE ${ }^{5}$, TETSUKAN WOO ${ }^{6}$, YASUSHI RINO ${ }^{2}$, MUNETAKA MASUDA ${ }^{2}$, \\ YOHEI MIYAGI ${ }^{4}$, HIROYUKI ITO $^{1}$ and HARUHIKO NAKAYAMA ${ }^{1}$ \\ ${ }^{1}$ Department of Thoracic Surgery, Kanagawa Cancer Center, Yokohama, Japan; \\ ${ }^{2}$ Department of Surgery, Yokohama City University, Yokohama, Japan; \\ ${ }^{3}$ Department of Gastrointestinal Surgery, Kanagawa Cancer Center, Yokohama, Japan; \\ ${ }^{4}$ Kanagawa Cancer Center Research Institute, Yokohama, Japan; \\ ${ }^{5}$ Department of Pathology, Kanagawa Cancer Center, Yokohama, Japan; \\ ${ }^{6}$ Respiratory Disease Center, Yokohama City University Medical Center, Yokohama, Japan
}

\begin{abstract}
Background: Cancer stem cells (CSCs) are involved in cancer metastasis and relapse. Therefore, identification of CSC biomarkers might help determine the success of a treatment. In this study, we examined the expression of four CSC markers: Cluster of differentiation 44 variant (CD44v), leucinerich repeat-containing G-protein-coupled receptor 5 (LGR5), frizzled 7 (FZD7), and muscle, intestine and stomach expression 1 (MIST1), in cancer tissues of patients with non-small-cell lung cancer at $>5$ years after resection, and its clinical significance. Patients and Methods: We examined the expression of each CSC marker in 360 patients with NSCLC $(n=360)$ who underwent curative resection by immunohistochemical analysis of tissue microarrays, and determined its relationship with survival. Results: High expression of MIST1 was related to better overall survival $(p<0.05)$; high CD44v expression was associated with poor overall and recurrence-free survival ( $p<0.001$ for both) and thus, CD44v was defined as an independent prognostic factor $(p<0.05)$, according to a multivariate analysis. Conclusion: Tumoral CD44v expression might be a useful prognostic marker for patients after curative resection of NSCLC.
\end{abstract}

Lung cancer is the most frequent malignant tumour with the highest mortality rate worldwide (1). Non-small-cell lung cancer

This article is freely accessible online.

Correspondence to: Dr. Takashi Oshima, Department of Gastrointestinal Surgery, Kanagawa Cancer Center, 2-3-2 Nakao Asahi, Yokohama, Kanagawa, Japan. Tel: +81 455202222, Fax: +81 455202202, e-mail: oshima@kcch.jp

Key Words: Non-small-cell lung cancer, cancer stem cell, prognostic marker.
(NSCLC) accounts for 80-85\% of all lung cancer and its best treatment is surgical intervention (2). However, even with curative resection, a 5-year survival rate of $64 \%$ is inadequate (3). Therefore, an improved treatment outcome, such as a treatment individualisation based on biomarkers, is necessary.

In 1997, cancer was confirmed to originate from a small number of cells, which have the self-replication and diversification characteristics of stem cells (4), cancer stem cells (CSCs) and then by 2000, CSCs were found in various types of cancer. Previous studies have reported that CSCs are resistant to various treatments, such as chemotherapy and radiation (58). Although CSCs are associated with patient survival, there is insufficient information regarding identification of CSC markers that are useful in predicting prognosis. Therefore, based on the data from The Cancer Genome Atlas and many previous reports on CSC markers, we studied four possible biomarkers of NSCLC: Cluster of differentiation 44 variant (CD44v), leucinerich-repeat-containing g-protein-coupled receptor 5 (LGR5), frizzled-7 (FZD7), and muscle, intestine and stomach expression 1 (MIST1).

CD44, a non-kinase transmembrane glycoprotein, plays a role in cancer development and progression $(9,10)$ and its expression in NSCLC is not clearly related to patient survival (11-18).

LGR5 is a target gene of the WNT signalling pathway and an intestinal epithelial stem cell marker (19). Studies have reported that LGR5 overexpression is associated with the prognosis of several malignant tumours (20-26). However, its association with lung cancer has not been determined.

MIST1 is a transcriptional factor of the basic helix-loophelix helix family and a CSC marker. Its mRNA was first observed in the developing lung bud during mouse embryogenesis (27) and then on mammalian lung cells. However, the clinical significance of MIST1 expression in lung cancer tissue has not been clarified. 
FZD receptors, FZD1 to FZD10, can respond to WNT proteins in the presence of WNT co-receptors to activate WNT pathways. FZD7 is the most commonly up-regulated FZD molecule in a variety of cancer types, including lung cancer $(28,29)$, and its mRNA overexpression was upregulated in lung adenocarcinoma cell lines, promoting cell viability and survival. In addition, FZD7 was reported to play an important role in stem cell biology and in cancer development and progression. However, its clinical significance in lung cancer has not been determined $(30,31)$.

With the evolution of cigarette composition, smoking habits, environmental, and lung cancer screening methods, the histological distribution of NSCLC is changing (32).

In this study, we investigated the clinical significance of the expression of these four CSC markers in cancer tissues of patients who had undergone curatively resected NSCLC.

\section{Patients and Methods}

Patients. This study was approved by the Research Ethics Committee of the Kanagawa Cancer Center prior to initiating the study (approval number: Epidemiological Study-2019-133). A total of 396 patients diagnosed with lung cancer who underwent surgery between August 2011 and August 2015 at the Kanagawa Cancer Center were selected from the clinical database. The inclusion criteria were: i) A pathological diagnosis of NSCLC, and ii) undergoing curative resection (R0). The exclusion criteria were: i) Death prior to discharge, ii) pathological diagnosis of stage IV, and iii) receipt of neoadjuvant chemotherapy/radiotherapy.

The tumour histology and the pathological stage were determined using the World Health Organization classification (33) and the seventh edition of the TNM classification for lung cancer (34), respectively.

Overall survival (OS) was measured from the operative day to death, and recurrence-free survival (RFS) from the operative day to tumour recurrence or death by any cause.

Immunohistochemical analysis using tissue microarray. Blocks containing formalin-fixed paraffin-embedded lung cancer tissues were selected by pathologists. The slides sectioned from the blocks were stained with haematoxylin and eosin (H\&E) and the central and peripheral parts of lung cancer tissues as well as the adjacent normal tissue were marked by a pathologist. Next, two central and two peripheral cores were collected from the marked areas of each block by using tissue cylinders. The four tissue sections were deparaffinised and soaked in $10 \mathrm{mM}$ sodium citrate buffer at $121^{\circ} \mathrm{C}$ for $20 \mathrm{~min}$. After blocking with 5\% skim milk in phosphate buffered saline with Tween ${ }^{\circledR}$ 20 (Takara Bio, Shiga, Japan), the sections were incubated overnight with anti-CD44v (1:500), anti-LGR5 (1:25), anti-MIST1 (1:100), and anti-FZD7 (1:125) primary antibodies (all Abcam PLC, Cambridge, $\mathrm{UK})$ at $4^{\circ} \mathrm{C}$. A peroxidase-labelled polymer (DAKO EnVision ${ }^{\mathrm{TM}}+$ System, HRP; DAKO, Glostrup, Denmark) was used to detect the signals. All sections were counterstained with H\&E.

Immunohistochemical evaluation of CD $44 \mathrm{v}$ immunostaining was performed based on the report published by Hirata et al. (11). Scores were assigned as a percentage of positive core. The mean percentage for four cores was considered representative of one tumour. CD44v expression was considered low or high, depending
Table I. Clinicopathological patient.

\begin{tabular}{|c|c|}
\hline Characteristic & Value \\
\hline \multicolumn{2}{|l|}{ Gender } \\
\hline Male & $203(56.4 \%)$ \\
\hline Female & $157(43.6 \%)$ \\
\hline \multicolumn{2}{|l|}{ Age } \\
\hline Median (range) & $68(35-90)$ \\
\hline$<69$ Years & $187(51.9 \%)$ \\
\hline$\geq 69$ Years & $173(48.1 \%)$ \\
\hline \multicolumn{2}{|l|}{ Smoking habit, n (\%) } \\
\hline Non smoker & $140(38.9 \%)$ \\
\hline Smoker & $220(61.1 \%)$ \\
\hline \multicolumn{2}{|l|}{ Serum CEA } \\
\hline$\leq 5.0 \mathrm{ng} / \mathrm{ml}$ & $284(78.9 \%)$ \\
\hline$>5.0 \mathrm{ng} / \mathrm{ml}$ & $76(21.1 \%)$ \\
\hline \multicolumn{2}{|l|}{ Surgical procedure, $\mathrm{n}(\%)$} \\
\hline Lobectomy or more & $286(79.4 \%)$ \\
\hline Segmentectomy & $26(7.2 \%)$ \\
\hline Wedge resection & $48(13.3 \%)$ \\
\hline \multicolumn{2}{|l|}{ Histological type, n (\%) } \\
\hline Adenocarcinoma & $290(80.6 \%)$ \\
\hline Squamous cell carcinoma & $36(10.0 \%)$ \\
\hline Large-cell carcinoma & $15(4.2 \%)$ \\
\hline Other & $19(5.3 \%)$ \\
\hline \multicolumn{2}{|l|}{ p-Stage*, n (\%) } \\
\hline I & $273(75.8 \%)$ \\
\hline II & $52(14.4 \%)$ \\
\hline III & $35(9.7 \%)$ \\
\hline \multicolumn{2}{|l|}{ pT Category, n (\%) } \\
\hline 1 & $176(48.9 \%)$ \\
\hline 2 & $163(45.3 \%)$ \\
\hline 3 & $21(5.9 \%)$ \\
\hline 4 & $0(0.0 \%)$ \\
\hline \multicolumn{2}{|l|}{ pN Category, n (\%) } \\
\hline 0 & $298(82.8 \%)$ \\
\hline 1 & $30(8.3 \%)$ \\
\hline 2 & $32(8.9 \%)$ \\
\hline \multicolumn{2}{|l|}{ Lymphatic invasion, $\mathrm{n}(\%)$} \\
\hline - & $289(80.3 \%)$ \\
\hline+ & $71(19.7 \%)$ \\
\hline \multicolumn{2}{|l|}{ Vessel invasion, $\mathrm{n}(\%)$} \\
\hline No & $249(69.2 \%)$ \\
\hline Yes & $111(30.8 \%)$ \\
\hline \multicolumn{2}{|l|}{ Pleural invasion, $\mathrm{n}(\%)$} \\
\hline No & $277(76.9 \%)$ \\
\hline Yes & $83(23.1 \%)$ \\
\hline \multicolumn{2}{|l|}{ Adjuvant chemotherapy, n (\%) } \\
\hline No & $282(78.3 \%)$ \\
\hline Yes & $78(21.7 \%)$ \\
\hline
\end{tabular}

*According to the seventh edition of the TNM classification for lung cancer (34).

on whether the percentage of positively stained cells was less than $20 \%$ or higher, respectively. Immunohistochemical evaluation of LGR5, MIST1, and FZD7 expression was performed according to a modified immunoreactivity scoring system (IRS). The maximum intensity of positively immunostained tumour cells was classified as absent (score 0 ), weak (score 1), moderate (score 2), and strong 

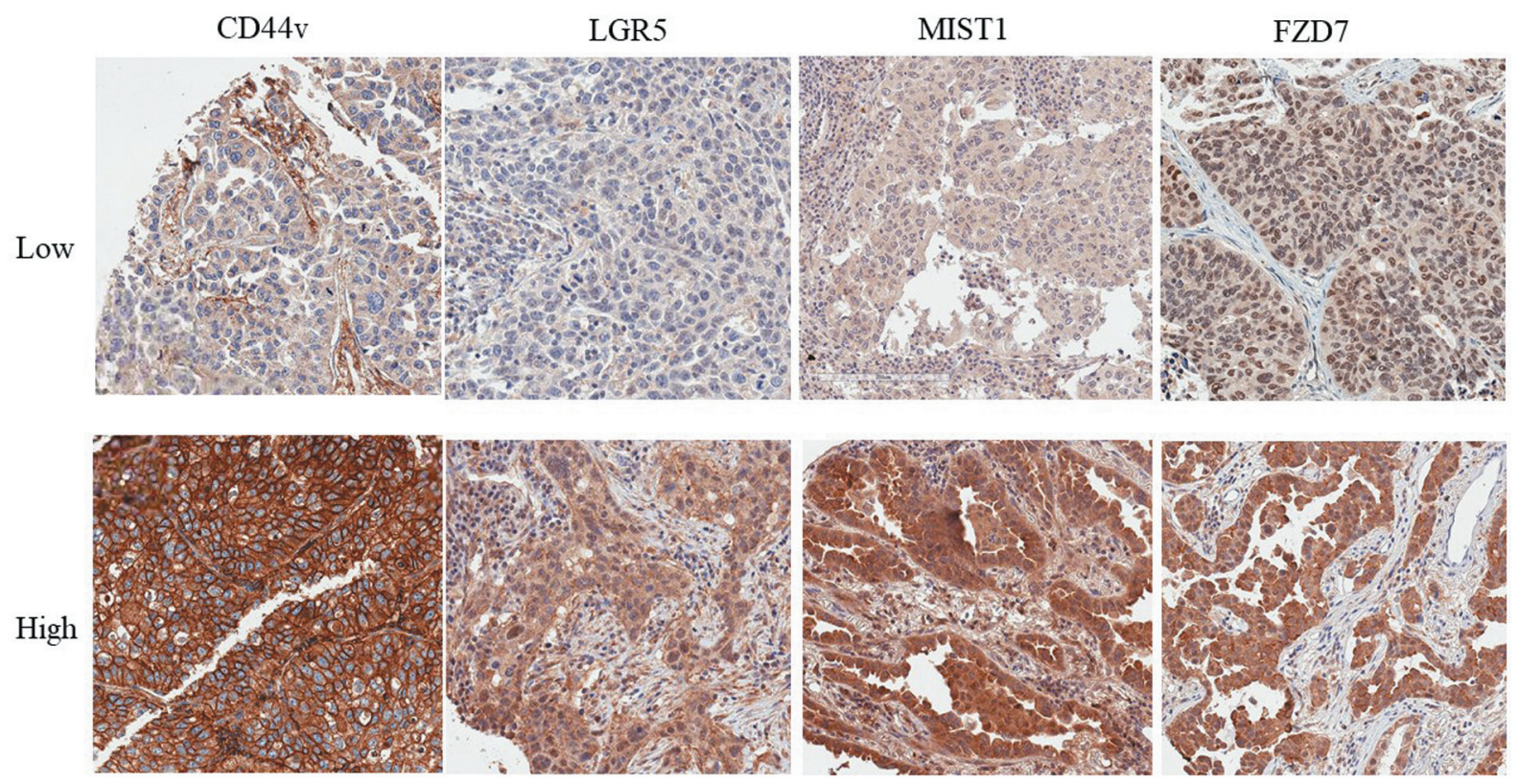

Figure 1. Representation high and low immunohistochemical expression of cluster of differentiation 44 variant (CD44v), leucine-rich repeatcontaining G-protein-coupled receptor 5 (LGR5), muscle, intestine and stomach expression 1 (MIST1) and frizzled 7 (FZD7) in non-small-cell lung cancer tissues. CD44v was located in the cell membrane, whereas LGR5, MIST1, and FZD7 were located in the cytoplasm and nucleus $\times 400$.

(score 3). The percentage of positively immunostained tumour cells was divided into four scores, namely $0,1,2$ and 3 , based on the marker-specific approach described by Grote et al. (35). Therefore, samples with $0 \%$ tumour cells immunostained for LGR5, MIST1, and FZD7 was scored as 0; tumour cell immunostaining of $0.1-19 \%$ for LGR5, 0.1-1\% MIST1, and 0.1$1 \%$ FZD7 were scored as 1 ; immunostaining of $20-49 \%$ for LGR5, $2-10 \%$ for MIST1, and 2-10\% for FZD7 were scored as 2; and a score of 3 for $\geq 50 \%$ LGR5, $\geq 11 \%$ MIST1 and $\geq 11 \%$ FZD7 immunostained tumour cells were scored as 3 . The scores percentage staining and intensity were added, resulting in IRS values of 0 to 6 . IRS values of between 0 to 4 were defined as representing low immunoreactivity and those between 5 and 6 as high immunoreactivity. All arrays were reviewed by two unblinded pathologists. Discordant cases were reviewed and discussed until a consensus was reached.

Statistical analysis. Survival curves were constructed according to the Kaplan-Meier method to evaluate the correlations between the expression of each CSC marker and the survival rate. The differences in survival between patients with high and those with low expression levels were analysed using the log-rank test. The relationships between expression levels of CSC markers and clinicopathological factors were assessed using Pearson's chisquared test. To Identify the factors involved in OS and RFS, the Cox proportional hazards model was used. The multivariate analysis included influencing factors with a value of $p<0.1$ in the univariate analysis. Statistical analyses of the results were performed using the SPSS 23.0 statistical package (IBM Corp., Armonk, NY, USA). For all tests, two-sided $p$-values of less than 0.05 were considered statistically significant.

\section{Results}

Characteristics of the study patients. The characteristics of the study patients are summarised in Table I. A total of 360 out of 396 patients $(91.1 \%)$ were included. The median follow-up period was 66.0 months. Regarding the histological cancer types: 290 cases presented adenocarcinoma, 36 squamous cell carcinoma, 15 large-cell carcinoma, and 19 other non-smallcell carcinomas, including carcinoid tumour $(n=1)$, and large cell neuroendocrine $(n=7)$, adenosquamous $(n=5)$, pleomorphic $(n=5)$, and unclassified $(n=1)$ carcinomas. Based on the pathological stage, disease in 273,52 , and 35 patients corresponded to stage I, II, and III, respectively.

CD44v, LGR5, FZD7, and MIST1 expression in NSCLC. Figure 1 shows representative expression of each CSC marker at low and high levels in cancer tissue. Rates of high expression of CD44v, LGR5, FZD7, and MIST1 were $15.2 \%, 67.7 \%, 16.2 \%$, and $23.9 \%$, respectively.

OS and RFS according to CD44v, LGR5, MIST1, and FZD7 expression levels. High CD44v expression was significantly correlated with worse OS and RFS $(p<0.001)$ when compared to low CD44v expression. The 5-year OS rates in patients with high and low CD44v expression were $64.3 \%$ and $83.8 \%$, respectively (Figure 2A), whereas the corresponding 5-year RFS rates were $48.9 \%$ and $74.8 \%$, respectively (Figure $3 \mathrm{~A}$ ). 
A

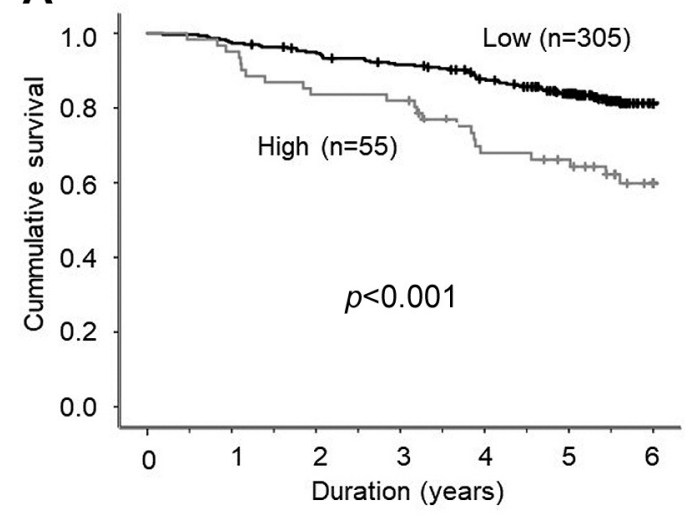

C

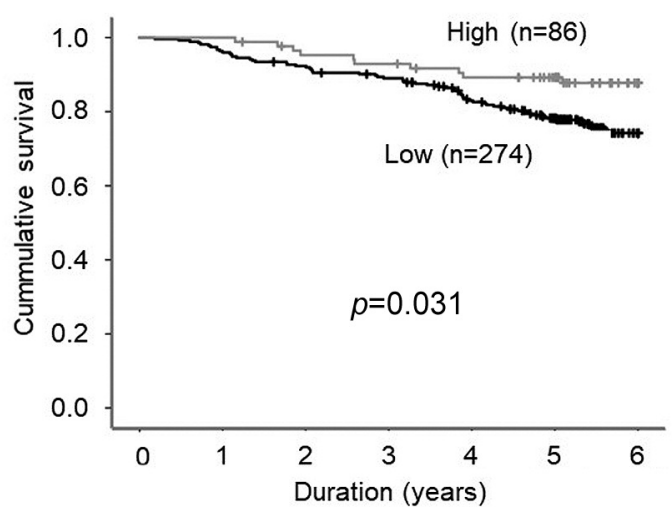

B

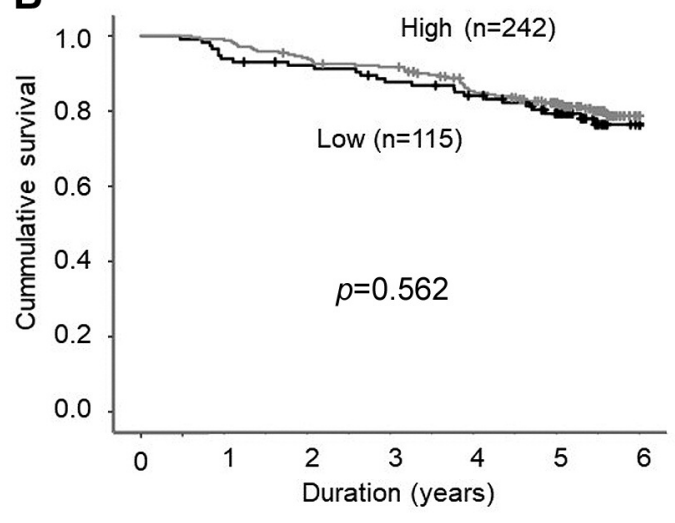

D

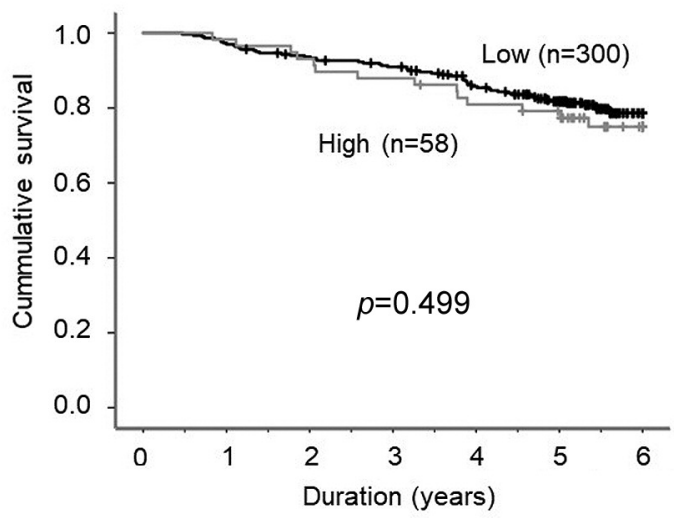

Figure 2. Overall survival according to cluster of differentiation 44 variant (CD44v) (A), leucine-rich repeat-containing G-protein-coupled receptor 5 (LGR5) (B), muscle, intestine and stomach expression 1 (MIST1) (C), and frizzled 7 (FZD7) (D) expression. High CD44v expression was significantly associated with a poor OS compared to that of the low CD44v expression group $(p<0.001)$. Low MIST1 expression was significantly poorer than that of the high MIST1 group ( $p=0.031)$. There was no significant difference in OS depending on the expression levels of LGR5 and FZD2.

However, low MIST1 expression was significantly associated with worse OS $(p=0.031)$ when compared to patients with high MIST1 expression (Figure 2C). The 5-year OS rates in patients with high and low MIST1 expression levels were $88.2 \%$ and $78.2 \%$, respectively. Analyses of LGR5 and FZD2 levels did not indicate significant differences in OS or RFS dependent on the expression levels.

Relationship between CD44v, LGR5, MIST1, and FZD7 expression levels and clinicopathological factors. Relationships between expression levels of these four CSC markers and clinicopathological factors are shown in Tables II and III. High expression of CD44v was significantly correlated with male sex, a smoking habit, histological type (squamous cell carcinoma), pathological T category (T2 or T3), and vessel and pleural invasion. High expression of MIST1 was significantly correlated with lower serum carcinoembryonic antigen (CEA) level, pathological stage I, and pathological category N0. High expression of LGR5 was significantly correlated with vessel invasion. However, no significant correlation between FZD7 expression levels and clinicopathological factors was noted.

Univariate and multivariate analyses of OS. According to the univariate analysis, sex, smoking habit, serum CEA level, histological type, pathological stage, lymphatic invasion, vessel invasion, CD44v expression, and MIST1 expression were selected as significant factors for OS. On the other hand, the multivariate analysis of OS indicated that serum CEA level, histological type, pathological stage, and CD44v positivity were independent factors for OS (Table IV).

Univariate and multivariate analyses of RFS. The univariate analysis of RFS revealed that sex, serum CEA level, surgical procedure, histological type, pathological stage, lymphatic invasion, vessel invasion, adjuvant chemotherapy, and CD44v expression were significant factors for RFS. However, only serum CEA level, pathological stage, histological type, 
A

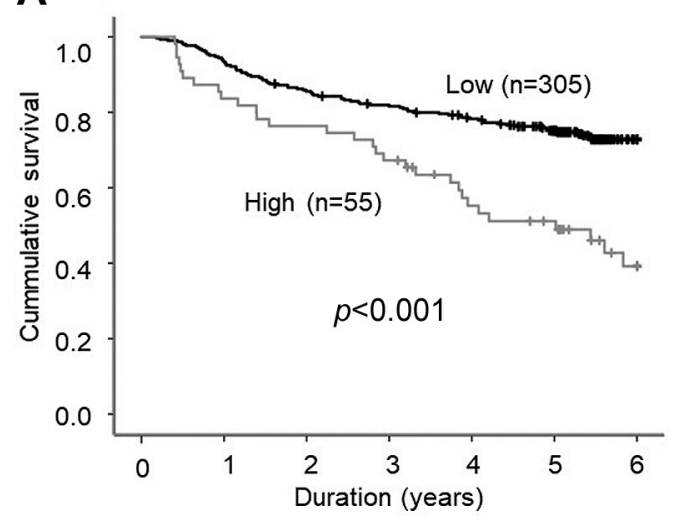

C

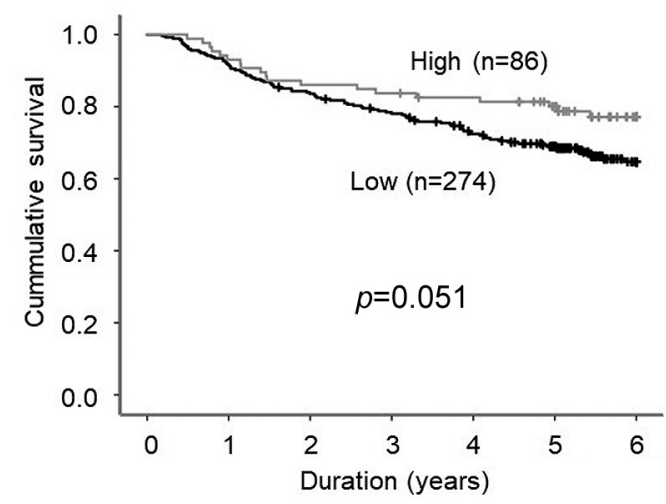

B

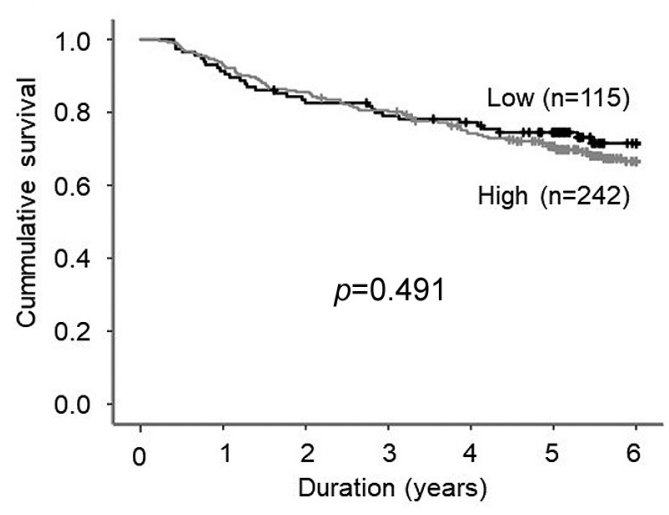

D

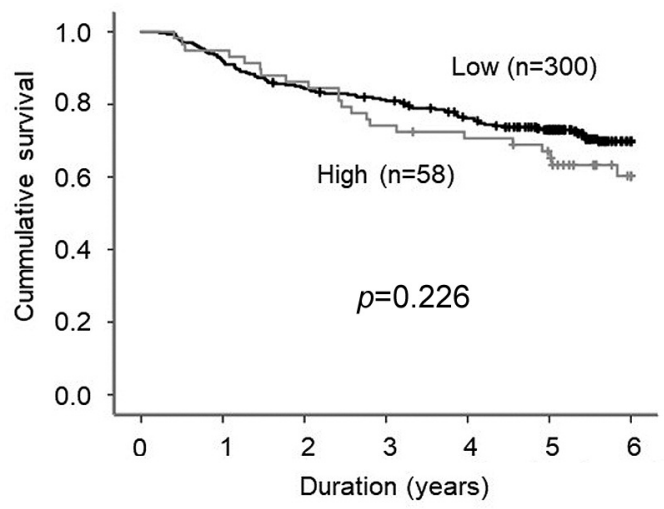

Figure 3. Recurrence-free survival (RFS) according to cluster of differentiation 44 variant (CD44v) (A), leucine-rich repeat-containing G-proteincoupled receptor 5 (LGR5) (B), muscle, intestine and stomach expression 1 (MIST1) (C), and frizzled 7 (FZD7) (D) expression. RFS of the group with high CD44v expression was significantly poorer than that with low CD44v expression. There was no significant difference in RFS depending on the expression levels of LGR5, MIST1 and FZD2.

lymphatic invasion, and CD44v expression were significant independent factors for RFS, based on the multivariate analysis of RFS (Table V).

\section{Discussion}

In the present study, we investigated whether the expression of CSC markers: CD44v, LGR5, FZD7, and MIST1 in cancer tissues of patients with NSCLC had clinical significance. Our results indicated that high expression of CD44v and low expression of MIST1 were significantly associated with poor outcomes and that CD44v expression was a useful prognostic factor in patients with NSCLC.

Several studies reported that high expression of CD44v was significantly associated with poor outcomes (11-13). However, others indicated the opposite $(14,15)$. Thus, the clinical significance of CD44v expression in NSCLC tissue was not clearly defined. A possible reason for this discrepancy might be that the conditions of these previous studies were different, including the ratio of the histological type, tumour stage, and ethnicity, and that those different conditions might lead to different results when studying the relationship between $\mathrm{CD} 44 \mathrm{v}$ expression and survival. In particular, the ratio of histological type was historically different. With the evolution of cigarette composition, smoking habits, environmental exposure, and lung cancer screening methods, the histological distribution of NSCLC is changing.

Two meta-analyses about the association between CD44v and NSCLC reported that high expression of CD44v was a poor prognostic factor $(16,17)$. However, the total number of patients in each study was smaller than that in this study, and several aspects were different.

The present study included the largest number of patients investigated for the true association between CD44v expression and survival compared to previous ones. Moreover, we used the latest samples and data with more than 5 years prognostic information. 
Table II. Relationship between Cluster of differentiation 44 variant (CD44v) and muscle, intestine, and stomach expression 1 (MIST1) expression and clinicopathological parameters.

\begin{tabular}{|c|c|c|c|c|c|c|}
\hline \multirow[b]{2}{*}{ Characteristic } & \multicolumn{3}{|c|}{ CD44v, n (\%) } & \multicolumn{3}{|c|}{ MIST1, n (\%) } \\
\hline & Low $(n=305)$ & High $(n=55)$ & $p$-Value & Low $(n=274)$ & High $(n=86)$ & $p$-Value \\
\hline \multicolumn{7}{|l|}{ Gender } \\
\hline Male & $155(76.4 \%)$ & $48(23.6 \%)$ & \multirow[t]{2}{*}{$<0.001$} & $158(77.8 \%)$ & $45(22.2 \%)$ & \multirow[t]{2}{*}{0.384} \\
\hline Female & $150(95.5 \%)$ & $7(4.5 \%)$ & & $116(91.7 \%)$ & $41(26.1 \%)$ & \\
\hline \multicolumn{7}{|l|}{ Age } \\
\hline$<69$ Years & $163(87.2 \%)$ & $24(12.8 \%)$ & \multirow[t]{2}{*}{0.108} & $144(77.0 \%)$ & $43(23.0 \%)$ & \multirow[t]{2}{*}{0.679} \\
\hline$\geq 69$ Years & $142(82.1 \%)$ & $31(17.9 \%)$ & & $130(75.1 \%)$ & $43(24.9 \%)$ & \\
\hline \multicolumn{7}{|l|}{ Smoking habit } \\
\hline Non smoker & $137(97.9 \%)$ & $3(2.1 \%)$ & \multirow[t]{2}{*}{$<0.001$} & $100(71.4 \%)$ & $40(28.6 \%)$ & \multirow{2}{*}{0.096} \\
\hline Smoker & $168(76.4 \%)$ & $52(23.6 \%)$ & & $174(79.1 \%)$ & $46(20.9 \%)$ & \\
\hline \multicolumn{7}{|l|}{ Serum CEA } \\
\hline$\leq 5.0 \mathrm{ng} / \mathrm{ml}$ & $244(85.9 \%)$ & $40(14.1 \%)$ & \multirow[t]{2}{*}{0.224} & $207(72.9 \%)$ & $77(27.1 \%)$ & \multirow[t]{2}{*}{0.006} \\
\hline$<5.0 \mathrm{ng} / \mathrm{ml}$ & $61(80.3 \%)$ & $15(19.7 \%)$ & & $67(88.2 \%)$ & $9(11.8 \%)$ & \\
\hline \multicolumn{7}{|l|}{ Surgical procedure } \\
\hline Lobectomy or more & $240(83.9 \%)$ & $46(16.1 \%)$ & \multirow[t]{2}{*}{0.403} & $220(76.9 \%)$ & $66(23.1 \%)$ & \multirow[t]{2}{*}{0.478} \\
\hline Sublobar resection & $65(87.8 \%)$ & $9(12.2 \%)$ & & $54(73.0 \%)$ & $20(27.0 \%)$ & \\
\hline \multicolumn{7}{|l|}{ Histological type } \\
\hline Overall & & & \multirow[t]{2}{*}{$<0.001$} & & & \multirow[t]{5}{*}{0.488} \\
\hline Adenocarcinoma & $276(95.2 \%)$ & $14(4.8 \%)$ & & $217(74.8 \%)$ & $73(25.2 \%)$ & \\
\hline Squamous cell carcinoma & $6(16.7 \%)$ & $30(83.3 \%)$ & $<0.001 v s$. other & $31(86.1 \%)$ & $5(13.9 \%)$ & \\
\hline Large-cell carcinoma & $9(60.0 \%)$ & $6(40.0 \%)$ & & $12(80.0 \%)$ & $3(20.0 \%)$ & \\
\hline Other & $14(73.7 \%)$ & $5(26.3 \%)$ & & $14(73.7 \%)$ & $5(26.3 \%)$ & \\
\hline p-Stage* & & & & & & \\
\hline Overall & & & 0.843 & & & 0.001 \\
\hline I & $233(85.3 \%)$ & $40(14.7 \%)$ & $0.608 v s$. II, III & $195(71.4 \%)$ & $78(28.6 \%)$ & $<0.001$ vs. II, II \\
\hline II & $43(82.7 \%)$ & $9(17.3 \%)$ & & $47(90.4 \%)$ & $5(9.6 \%)$ & \\
\hline III & $29(85.3 \%)$ & $5(14.7 \%)$ & & $32(91.4 \%)$ & $3(8.6 \%)$ & \\
\hline pT Category & & & & & & \\
\hline Overall & & & 0.030 & & & 0.151 \\
\hline 1 & $158(89.8 \%)$ & $18(10.2 \%)$ & $\mathbf{0 . 0 0 9}$ vs. 2,3 & $128(72.7 \%)$ & $48(27.3 \%)$ & 0.141 vs. 2,3 \\
\hline 2 & $131(80.4 \%)$ & $32(19.6 \%)$ & & $127(77.9 \%)$ & $36(22.1 \%)$ & \\
\hline 3 & $16(76.2 \%)$ & $5(23.8 \%)$ & & $19(90.5 \%)$ & $2(9.5 \%)$ & \\
\hline pN Category & & & & & & \\
\hline Overall & & & 0.817 & & & 0.006 \\
\hline 0 & $254(85.2 \%)$ & $44(14.8 \%)$ & 0.553 vs. 1,2 & $217(72.8 \%)$ & $81(27.2 \%)$ & $0.001 v s .1,2$ \\
\hline 1 & $25(83.3 \%)$ & $5(16.7 \%)$ & & $28(93.3 \%)$ & $2(6.7 \%)$ & \\
\hline 2 & $26(81.3 \%)$ & $6(18.8 \%)$ & & $29(90.6 \%)$ & $3(9.4 \%)$ & \\
\hline Lymphatic invasion & & & & & & \\
\hline No & $247(85.5 \%)$ & $42(14.5 \%)$ & 0.428 & $217(75.1 \%)$ & $72(24.9 \%)$ & 0.358 \\
\hline Yes & $58(81.7 \%)$ & $13(18.3 \%)$ & & $57(80.3 \%)$ & $14(19.7 \%)$ & \\
\hline Vessel invasion & & & & & & \\
\hline No & $223(89.6 \%)$ & $26(10.4 \%)$ & $<0.001$ & $187(75.1 \%)$ & $62(24.9 \%)$ & 0.501 \\
\hline Yes & $82(73.9 \%)$ & $29(26.1 \%)$ & & $87(78.4 \%)$ & $24(21.6 \%)$ & \\
\hline Pleural invasion & & & & & & \\
\hline No & $241(87.0 \%)$ & $36(13.0 \%)$ & 0.028 & $211(76.2 \%)$ & $66(23.8 \%)$ & 0.960 \\
\hline Yes & $64(77.1 \%)$ & $19(22.9 \%)$ & & $63(75.9 \%)$ & $20(24.1 \%)$ & \\
\hline Adjuvant chemotherapy & & & & & & \\
\hline No & $238(84.4 \%)$ & $44(15.6 \%)$ & 0.744 & $211(74.8 \%)$ & $71(25.2 \%)$ & 0.276 \\
\hline Yes & $67(85.9 \%)$ & $11(14.1 \%)$ & & $63(80.8 \%)$ & $15(19.2 \%)$ & \\
\hline
\end{tabular}

*According to the seventh edition of the TNM classification for lung cancer (34). Statistically significant $p$-values are shown in bold.

Moreover, this study is the first to report the association between MIST1 and NSCLC. We demonstrated that the high expression of MIST1 was significantly associated with better OS and correlated with better prognostic factors, including low CEA level, pathological stage I, and pN0 category. A previous study showed that MIST1 functioned as a tumour suppressor in mice and that MIST1 protein and mRNA expression were both down-regulated in a pancreatic cancer 
Table III. Relationship between leucin-rich-repeat-containing g-protein-coupled receptor 5 (LGR5) and frizzled-7 (FZD7) expression and clinicopathological parameters.

\begin{tabular}{|c|c|c|c|c|c|c|}
\hline \multirow[b]{2}{*}{ Characteristic } & \multicolumn{3}{|c|}{ LGR5, n (\%) } & \multicolumn{3}{|c|}{ FZD7, n (\%) } \\
\hline & Low $(n=115)$ & High $(n=242)$ & $p$-Value & Low $(n=300)$ & High $(\mathrm{n}=58)$ & $p$-Value \\
\hline \multicolumn{7}{|l|}{ Gender } \\
\hline Male & $67(33.3 \%)$ & $134(66.7 \%)$ & \multirow[t]{2}{*}{0.607} & $169(84.1 \%)$ & $32(15.9 \%)$ & \multirow[t]{2}{*}{0.870} \\
\hline Female & $48(30.8 \%)$ & $108(69.2 \%)$ & & $131(83.4 \%)$ & $26(16.6 \%)$ & \\
\hline \multicolumn{7}{|l|}{ Age } \\
\hline$<69$ Years & $52(28.1 \%)$ & $133(71.9 \%)$ & \multirow[t]{2}{*}{0.085} & $156(83.9 \%)$ & $30(16.1 \%)$ & \multirow[t]{2}{*}{0.969} \\
\hline$\geq 69$ Years & $63(36.6 \%)$ & $109(63.4 \%)$ & & $144(83.7 \%)$ & $28(16.3 \%)$ & \\
\hline \multicolumn{7}{|l|}{ Smoking habit } \\
\hline Non smoker & $41(29.5 \%)$ & $98(70.5 \%)$ & \multirow[t]{2}{*}{0.380} & $116(82.9 \%)$ & $24(17.1 \%)$ & \multirow[t]{2}{*}{0.698} \\
\hline Smoker & $74(33.9 \%)$ & $144(66.1 \%)$ & & $184(84.4 \%)$ & $34(15.6 \%)$ & \\
\hline \multicolumn{7}{|l|}{ Serum CEA } \\
\hline$\leq 5.0(\mathrm{ng} / \mathrm{ml})$ & $89(31.4 \%)$ & $194(68.6 \%)$ & \multirow[t]{2}{*}{0.546} & $239(84.2 \%)$ & $45(15.8 \%)$ & \multirow[t]{2}{*}{0.720} \\
\hline$<5.0(\mathrm{ng} / \mathrm{ml})$ & $26(35.1 \%)$ & $48(64.9 \%)$ & & $61(82.4 \%)$ & $13(17.6 \%)$ & \\
\hline \multicolumn{7}{|l|}{ Surgical procedure } \\
\hline Lobectomy or more & $91(32.2 \%)$ & $192(67.8 \%)$ & \multirow[t]{2}{*}{0.964} & $235(82.7 \%)$ & $49(17.3 \%)$ & \multirow[t]{2}{*}{0.290} \\
\hline Sublobar resection & $24(32.4 \%)$ & $50(67.6 \%)$ & & $65(87.8 \%)$ & $9(12.2 \%)$ & \\
\hline \multicolumn{7}{|l|}{ Histological type } \\
\hline Adenocarcinoma & $89(31.0 \%)$ & $198(69.0 \%)$ & \multirow[t]{4}{*}{0.560} & $239(83.0 \%)$ & $49(17.0 \%)$ & \multirow[t]{4}{*}{0.732} \\
\hline Squamous cell carcinoma & $15(41.7 \%)$ & $21(58.3 \%)$ & & $31(86.1 \%)$ & $5(13.9 \%)$ & \\
\hline Large-cell carcinoma & $4(26.7 \%)$ & $11(73.3 \%)$ & & $14(93.3 \%)$ & $1(6.7 \%)$ & \\
\hline Other & $7(36.8 \%)$ & $12(63.2 \%)$ & & $16(84.2 \%)$ & $3(15.8 \%)$ & \\
\hline p-Stage* & & & & & & \\
\hline Overall & & & 0.826 & & & 0.157 \\
\hline I & $86(31.6 \%)$ & $186(68.4 \%)$ & $0.667 v s$. II, III & $227(83.2 \%)$ & $46(16.8 \%)$ & 0.551 vs. II, II \\
\hline II & $18(36.0 \%)$ & $32(64.0 \%)$ & & $46(92.0 \%)$ & $4(8.0 \%)$ & \\
\hline III & $11(31.4 \%)$ & $24(68.6 \%)$ & & $27(77.1 \%)$ & $8(22.9 \%)$ & \\
\hline pT Category & & & & & & \\
\hline Overall & & & 0.066 & & & 0.745 \\
\hline 1 & $51(29.3 \%)$ & $123(70.7 \%)$ & 0.252 vs. 2,3 & $145(82.9 \%)$ & $30(17.1 \%)$ & $0.636 v s .2,3$ \\
\hline 2 & $53(32.5 \%)$ & $110(67.5 \%)$ & & $139(85.3 \%)$ & $24(14.7 \%)$ & \\
\hline 3 & $11(55.0 \%)$ & $9(45.0 \%)$ & & $16(80.0 \%)$ & $4(20.0 \%)$ & \\
\hline pN Category & & & & & & \\
\hline Overall & & & 0.852 & & & 0.474 \\
\hline 0 & $96(32.4 \%)$ & $200(67.6 \%)$ & 0.845 vs. 1,2 & $249(83.8 \%)$ & $48(16.2 \%)$ & 0.964 vs. 1,2 \\
\hline 1 & $10(34.5 \%)$ & $19(65.5 \%)$ & & $26(89.7 \%)$ & $3(10.3 \%)$ & \\
\hline 2 & $9(28.1 \%)$ & $23(71.9 \%)$ & & $25(78.1 \%)$ & $7(21.9 \%)$ & \\
\hline Lymphatic invasion & & & & & & \\
\hline No & $96(33.4 \%)$ & $191(66.6 \%)$ & 0.311 & $242(84.0 \%)$ & $46(16.0 \%)$ & 0.812 \\
\hline Yes & $19(27.1 \%)$ & $51(72.9 \%)$ & & $58(82.9 \%)$ & $12(17.1 \%)$ & \\
\hline Vessel invasion & & & & & & \\
\hline No & $88(35.6 \%)$ & $159(64.4 \%)$ & 0.039 & $208(83.9 \%)$ & $40(16.1 \%)$ & 0.956 \\
\hline Yes & $27(24.5 \%)$ & $83(75.5 \%)$ & & $92(83.6 \%)$ & $18(16.4 \%)$ & \\
\hline Pleural invasion & & & & & & \\
\hline No & $92(33.5 \%)$ & $183(66.5 \%)$ & 0.358 & $228(82.6 \%)$ & $48(17.4 \%)$ & 0.262 \\
\hline Yes & $23(28.0 \%)$ & $59(72.0 \%)$ & & $72(87.8 \%)$ & $10(12.2 \%)$ & \\
\hline Adjuvant chemotherapy & & & & & & \\
\hline No & $90(31.1 \%)$ & $189(67.7 \%)$ & 0.972 & $238(85.0 \%)$ & $42(15.0 \%)$ & 0.243 \\
\hline Yes & $25(32.1 \%)$ & $53(67.9 \%)$ & & $62(79.5 \%)$ & $16(20.5 \%)$ & \\
\hline
\end{tabular}

*According to the seventh edition of the TNM classification for lung cancer (34).

cell line (36). Moreover, overexpression of MISTI reversed the epithelial-mesenchymal transition by down-regulating snail family transcriptional repressor 1 (SNAI1) and upregulating E-cadherin (36).
Regarding LGR5, two studies showed that high expression of LGR5 was significantly associated with poor prognosis in patients with NSCLC and lung adenocarcinoma $(24,25)$. However, the LGR5 expression level was not associated with 
Table IV. Uni- and multivariate analyses of overall survival in patients with non-small-cell lung cancer ( $n=360)$.

\begin{tabular}{|c|c|c|c|c|c|}
\hline \multirow[b]{2}{*}{ Factor } & \multirow[b]{2}{*}{ Comparison } & \multicolumn{2}{|c|}{ Univariate } & \multicolumn{2}{|c|}{ Multivariate } \\
\hline & & HR (95\% CI) & $p$-Value & $\mathrm{HR}(95 \% \mathrm{CI})$ & $p$-Value \\
\hline Gender & Male $v s$. female & $0.479(0.291-0.786)$ & 0.004 & $0.782(0.365-1.674)$ & 0.527 \\
\hline Age & $<69 v s . \geq 69$ Years & $1.349(0.859-2.119)$ & 0.193 & & \\
\hline Smoking habit & No $v s$. yes & $1.965(1.179-3.275)$ & 0.010 & $0.870(0.392-1.932)$ & 0.732 \\
\hline CEA & $\leq 5.0 \mathrm{vs} .<5.0 \mathrm{ng} / \mathrm{ml}$ & $3.647(2.318-5.740)$ & $<0.001$ & $2.939(1.828-4.725)$ & $<0.001$ \\
\hline Surgical procedure & Sublobar resection $v s$. lobectomy or more & $1.203(0.673-2.149)$ & 0.532 & & \\
\hline \multirow[t]{4}{*}{ Histological type } & Adenocarcinoma & Reference & & Reference & \\
\hline & Squamous cell carcinoma & $2.965(1.629-5.397)$ & $<0.001$ & $1.686(0.742-3.834)$ & 0.212 \\
\hline & Large-cell carcinoma & $3.129(1.336-7.331)$ & 0.009 & $1.924(0.779-4.752)$ & 0.156 \\
\hline & Other & $4.893(2.464-9.715)$ & $<0.001$ & $4.077(1.908-8.711)$ & $<0.001$ \\
\hline Pathological stage* & I $v s$. II, III & $3.031(1.927-4.765)$ & $<0.001$ & $2.064(1.179-3.613)$ & 0.011 \\
\hline Lymphatic invasion & No $v s$. yes & $2.597(1.623-4.156)$ & $<0.001$ & $1.354(0.784-2.338)$ & 0.277 \\
\hline Vessel invasion & No $v s$. yes & $2.464(1.569-3.868)$ & $<0.001$ & $1.084(0.644-1.824)$ & 0.762 \\
\hline Adjuvant chemotherapy & No $v s$. yes & $1.034(0.603-1.774)$ & 0.903 & & \\
\hline CD44v expression & Low vs. high & $2.974(1.822-4.857)$ & $<0.001$ & $2.104(1.078-4.106)$ & 0.029 \\
\hline LGR5 expression & Low $v s$. high & $0.834(0.517-1.344)$ & 0.456 & & \\
\hline FZD7 expression & Low $v s$. high & $1.202(0.672-2.150)$ & 0.536 & & \\
\hline MIST1 expression & Low $v s$. high & $0.502(0.265-0.952)$ & 0.035 & $0.753(0.386-1.471)$ & 0.407 \\
\hline
\end{tabular}

Cluster of differentiation 44 variant (CD44v), leucin-rich-repeat-containing g-protein-coupled receptor 5 (LGR5), frizzled-7 (FZD7), and muscle, and intestine, and stomach expression 1 (MIST1). *According to the seventh edition of the TNM classification for lung cancer (34). Statistically significant $p$-values are shown in bold.

Table V. Uni- and multivariate analyses of recurrence-free survival in patients with non-small-cell lung cancer $(n=360)$.

\begin{tabular}{|c|c|c|c|c|c|}
\hline \multirow[b]{2}{*}{ Factor } & \multirow[b]{2}{*}{ Comparison } & \multicolumn{2}{|c|}{ Univariate } & \multicolumn{2}{|c|}{ Multivariate } \\
\hline & & $\mathrm{HR}(95 \% \mathrm{CI})$ & $p$-Value & HR $(95 \%$ CI $)$ & $p$-Value \\
\hline Gender & Male $v s$. female & $0.642(0.434-0.949)$ & 0.026 & $0.885(0.489-1.602)$ & 0.687 \\
\hline Age & $<69 v s . \geq 69$ Years & $0.923(0.635-1.343)$ & 0.667 & & \\
\hline Smoking habit & No $v s$. yes & $1.490(0.997-2.225)$ & 0.052 & $0.856(0.458-1.599)$ & 0.626 \\
\hline CEA & $\leq 5.0 \mathrm{vs} .<5.0 \mathrm{ng} / \mathrm{ml}$ & $2.524(1.706-3.734)$ & $<0.001$ & $1.673(1.107-2.527)$ & 0.015 \\
\hline Surgical procedure & Sublobar resection $v s$. lobectomy or more & $1.820(1.055-3.139)$ & $\mathbf{0 . 0 3 1}$ & $0.714(0.485-1.642)$ & 0.714 \\
\hline \multirow[t]{4}{*}{ Histological type } & Adenocarcinoma & Reference & & Reference & \\
\hline & Squamous cell carcinoma & $1.947(1.135-3.339)$ & 0.016 & $1.189(0.586-2.410)$ & 0.632 \\
\hline & Large-cell carcinoma & $2.243(1.034-4.867)$ & 0.041 & $1.446(0.632-3.307)$ & 0.382 \\
\hline & Other & $3.208(1.701-6.052)$ & $<0.001$ & $2.165(1.086-4.317)$ & 0.028 \\
\hline Pathological stage* & I $v s$. II, III & $4.037(2.773-5.877)$ & $<0.001$ & $2.335(1.424-3.828)$ & 0.001 \\
\hline Lymphatic invasion & No vs. yes & $3.330(2.267-4.891)$ & $<0.001$ & $1.613(1.028-2.531)$ & 0.038 \\
\hline Vessel invasion & No $v s$. yes & $3.194(2.195-4.648)$ & $<0.001$ & $1.514(0.970-2.361)$ & 0.068 \\
\hline Adjuvant chemotherapy & No $v s$. yes & $2.000(1.346-2.972)$ & $<0.001$ & $1.236(0.796-1.920)$ & 0.345 \\
\hline CD44v expression & Low $v s$. high & $2.519(1.654-3.836)$ & $<0.001$ & $2.051(1.176-3.578)$ & 0.011 \\
\hline LGR5 expression & Low $v s$. high & $1.158(0.763-1.757)$ & 0.491 & & \\
\hline FZD7 expression & Low $v s$. high & $1.334(0.835-2.130)$ & 0.228 & & \\
\hline MIST1 expression & Low $v s$. high & $0.614(0.374-1.007)$ & 0.053 & $0.872(0.516-1.473)$ & 0.608 \\
\hline
\end{tabular}

CD44v Cluster of differentiation 44 variant; LGR5: leucine-rich-repeat-containing G-protein-coupled receptor 5; FZD7: frizzled-7; MIST1: muscle, and intestine, and stomach expression 1. *According to the seventh edition of the TNM classification for lung cancer (34). Statistically significant p-values are shown in bold.

survival in our patients. Previous examination of the relationship between LGR5 expression and clinicopathological factors indicated an association between pathological stage and tumour size (24-26). However, in our study, although high expression of
LGR5 was associated with vessel invasion, expression of LGR5 was not associated with pathological stage and tumour size.

Some studies indicated that expression of FZD7 mRNA was up-regulated in lung adenocarcinoma cell lines and 
promoted cell viability and survival $(30,31)$. However, in this study, the expression levels of FZD7 were not significantly associated with survival even when in the adenocarcinoma subgroup analysis.

Our study had several limitations. Firstly, although this study was conducted using a relatively large number of patients with NSCLC $(n=360)$, it was a single-centre, retrospective study. To obtain more reliable results regarding the clinical significance of CSC markers, a multicentre study with a larger number of cases is necessary. Secondly, in this study, we examined the CSC marker levels at the central and peripheral regions of each NSCLC tissue by immunostaining; however, considering tumour heterogeneity, the expression levels of the CSC markers at these four regions might not be representative of the whole tumour.

In conclusion, the $\mathrm{CD} 44 \mathrm{v}$ level in tumour tissues might be a useful clinical prognostic marker for patients undergo curatively resected NSCLC.

\section{Conflicts of Interest}

All Authors have no conflicts of interest or financial ties to disclose.

\section{Authors' Contributions}

Concept and study design were by Oshima T, Nagashima T, Hiroshima $\mathrm{Y}$, and Miyagi Y. Data collection and literature searches were conducted by Nagashima T, and Ito H. Data analysis and interpretation were performed by Nagashima T, Oshima T, Hiroshima Y, and Miyagi Y. Data interpretation was carried out by all investigators. The article and figures were drafted by Nagashima $\mathrm{T}$ and Oshima $\mathrm{T}$. Finally, this article was revised and approved by all investigators.

\section{Acknowledgements}

The Authors thank the patients, their families, and the site staff for their participation in this study.

\section{References}

1 Mao Y, Yang D, He J and Krasna MJ: Epidemiology of lung cancer. Surg Oncol Clin N Am 25(3): 439-445, 2016. PMID: 27261907. DOI: $10.1016 /$ j.soc.2016.02.001

2 Hoy H, Lynch T and Beck M: Surgical treatment of lung cancer. Crit Care Nurs Clin North Am 31(3): 303-313, 2019. PMID: 31351552. DOI: $10.1016 /$ j.cnc.2019.05.002

3 Osarogiagbon RU, Faris NR, Stevens W, Fehnel C, Houston-Harris C, Ojeabulu P, Akinbobola OA, Lee YS, Ray MA and Smeltzer MP: Beyond margin status: Population-based validation of the proposed International Association for the Study of Lung Cancer residual tumor classification recategorization. J Thorac Oncol 15(3): 371-382, 2020. PMID: 31783180. DOI: 10.1016/j.jtho.2019.11.009

4 Bonnet D and Dick JE: Human acute myeloid leukemia is organized as a hierarchy that originates from a primitive hematopoietic cell. Nat Med 3(7): 730-737, 1997. PMID: 9212098. DOI: $10.1038 / \mathrm{nm} 0797-730$
5 Prabavathy D, Swarnalatha Y and Ramadoss N: Lung cancer stem cells - origin, characteristics and therapy. Stem Cell Investig 5: 6, 2018. PMID: 29682513. DOI: 10.21037/sci.2018.02.01

6 Chen J, Wang J, Zhang Y, Chen D, Yang C, Kai C, Wang X, Shi $\mathrm{F}$ and Dou J: Observation of ovarian cancer stem cell behavior and investigation of potential mechanisms of drug resistance in three-dimensional cell culture. J Biosci Bioeng 118(2): 214-222, 2014. PMID: 24684961. DOI: 10.1016/j.jbiosc.2014.01.008

7 Suda K, Murakami I, Yu H, Kim J, Tan AC, Mizuuchi H, Rozeboom L, Ellison K, Rivard CJ, Mitsudomi T and Hirsch FR: Cd44 facilitates epithelial-to-mesenchymal transition phenotypic change at acquisition of resistance to EGFR kinase inhibitors in lung cancer. Mol Cancer Ther 17(10): 2257-2265, 2018. PMID: 30049789. DOI: 10.1158/1535-7163.Mct-17-1279

8 Wang JL, Yu JP, Sun ZQ and Sun SP: Radiobiological characteristics of cancer stem cells from esophageal cancer cell lines. World J Gastroenterol 20(48): 18296-18305, 2014. PMID: 25561796. DOI: $10.3748 /$ wjg.v20.i48.18296

9 Chen C, Zhao S, Karnad A and Freeman JW: The biology and role of CD44 in cancer progression: Therapeutic implications. J Hematol Oncol 11(1): 64, 2018. PMID: 29747682. DOI: 10.1186/s13045-018-0605-5

10 Wang L, Zuo X, Xie K and Wei D: The role of CD44 and cancer stem cells. Methods Mol Biol 1692: 31-42, 2018. PMID: 28986884. DOI: 10.1007/978-1-4939-7401-6_3

11 Hirata T, Fukuse T, Naiki H, Hitomi S and Wada H: Expression of $C D 44$ variant exon 6 in stage I non-small cell lung carcinoma as a prognostic factor. Cancer Res 58(6): 1108-1110, 1998. PMID: 9515789.

12 Sun BS, Li Y, Zhang ZF, You J and Wang CL: Osteopontin combined with CD44v6, a novel prognostic biomarker in nonsmall cell lung cancer undergoing curative resection. Ann Thorac Surg 96(6): 1943-1951, 2013. PMID: 24094519. DOI: 10.1016/j.athoracsur.2013.07.089

13 Le QT, Chen E, Salim A, Cao H, Kong CS, Whyte R, Donington J, Cannon W, Wakelee H, Tibshirani R, Mitchell JD, Richardson D, O'Byrne KJ, Koong AC and Giaccia AJ: An evaluation of tumor oxygenation and gene expression in patients with early stage non-small cell lung cancers. Clin Cancer Res 12(5): 1507-1514, 2006. PMID: 16533775. DOI: 10.1158/1078-0432.Ccr-05-2049

14 Situ D, Long H, Lin P, Zhu Z, Wang J, Zhang X, Xie Z and Rong T: Expression and prognostic relevance of CD44v6 in stage I nonsmall cell lung carcinoma. J Cancer Res Clin Oncol 136(8): 12131219, 2010. PMID: 20127360. DOI: 10.1007/s00432-010-0771-5

15 Ramasami S, Kerr KM, Chapman AD, King G, Cockburn JS and Jeffrey RR: Expression of CD44v6 but not E-cadherin or betacatenin influences prognosis in primary pulmonary adenocarcinoma. J Pathol 192(4): 427-432, 2000. PMID: 11113858. DOI: 10.1002/1096-9896(2000)9999:9999<::Aid-path741>3.0.Co;2-Z

16 Zhao S, He JL, Qiu ZX, Chen NY, Luo Z, Chen BJ and Li WM: Prognostic value of $C D 44$ variant exon 6 expression in non-small cell lung cancer: A meta-analysis. Asian Pac J Cancer Prev 15(16): 6761-6766, 2014. PMID: 25169522. DOI: 10.7314/apjcp.2014. 15.16.6761

17 Jiang H, Zhao W and Shao W: Prognostic value of CD44 and CD44v6 expression in patients with non-small cell lung cancer: Meta-analysis. Tumour Biol 35(8): 7383-7389, 2014. PMID: 24913707. DOI: 10.1007/s13277-014-2150-3

18 Luo Z, Wu RR, Lv L, Li P, Zhang LY, Hao QL and Li W: Prognostic value of CD44 expression in non-small cell lung 
cancer: A systematic review. Int J Clin Exp Pathol 7(7): 36323646, 2014. PMID: 25120740.

19 de Lau W, Peng WC, Gros P and Clevers H: The Rspondin/LGR5/RNF43 module: Regulator of Wnt signal strength. Genes Dev 28(4): 305-316, 2014. PMID: 24532711. DOI: $10.1101 / \mathrm{gad} .235473 .113$

20 Wang W, Wan L, Wu S, Yang J, Zhou Y, Liu F, Wu Z and Cheng Y: Mesenchymal marker and LGR5 expression levels in circulating tumor cells correlate with colorectal cancer prognosis. Cell Oncol 41(5): 495-504, 2018. PMID: 29949050. DOI: $10.1007 / \mathrm{s} 13402-018-0386-4$

21 Liu XS, Lin XK, Mei Y, Ahmad S, Yan CX, Jin HL, Yu H, Chen $\mathrm{C}$, Lin $\mathrm{CZ}$ and $\mathrm{Yu}$ JR: Regulatory $\mathrm{T}$ cells promote overexpression of LGR5 on gastric cancer cells via TGF-beta1 and confer poor prognosis in gastric cancer. Front Immunol 10: 1741, 2019. PMID: 31417548. DOI: 10.3389/fimmu.2019.01741

22 Zhang J, Cai H, Sun L, Zhan P, Chen M, Zhang F, Ran Y and Wan J: Lgr5, a novel functional glioma stem cell marker, promotes EMT by activating the $\mathrm{Wnt} / \beta$-catenin pathway and predicts poor survival of glioma patients. J Exp Clin Cancer Res 37(1): 225, 2018. PMID: 30208924. DOI: 10.1186/s13046-0180864-6

23 Hou MF, Chen PM and Chu PY: LGR5 overexpression confers poor relapse-free survival in breast cancer patients. BMC Cancer 18(1): 219, 2018. PMID: 29471794. DOI: 10.1186/s12885-0184018-1

24 Gao F, Zhou B, Xu JC, Gao X, Li SX, Zhu GC, Zhang XG and Yang C: The role of LGR5 and ALDH1A1 in non-small cell lung cancer: Cancer progression and prognosis. Biochem Biophys Res Commun 462(2): 91-98, 2015. PMID: 25881507. DOI: $10.1016 /$ j.bbrc.2015.04.029

25 Ryuge S, Sato Y, Jiang SX, Wang G, Kobayashi M, Nagashio R, Katono K, Iyoda A, Satoh $\mathrm{Y}$ and Masuda N: The clinicopathological significance of LGR5 expression in lung adenocarcinoma. Lung Cancer 82(1): 143-148, 2013. PMID: 23915911. DOI: 10.1016/j.lungcan.2013.06.010

26 Zhang X, Xu M, Su S, Zhou Z, Yang H, Zhao S, Zeng D, Yang $\mathrm{K}$, Liu Y, Wang L and Li J: LGR5-positive cells in the lung and their clinical significance in patients with lung adenocarcinoma. Mol Clin Oncol 5(2): 283-288, 2016. PMID: 27446565. DOI: $10.3892 / \mathrm{mco} .2016 .934$

27 Lemercier C, To RQ, Swanson BJ, Lyons GE and Konieczny SF: MIST1: A novel basic helix-loop-helix transcription factor exhibits a developmentally regulated expression pattern. Dev Biol 182(1): 101-113, 1997. PMID: 9073453. DOI: 10.1006/dbio.1996.8454
28 King TD, Zhang W, Suto MJ and Li Y: Frizzled7 as an emerging target for cancer therapy. Cell Signal 24(4): 846-851, 2012. PMID: 22182510. DOI: 10.1016/j.cellsig.2011.12.009

29 Fujiya K, Ohshima K, Kitagawa Y, Hatakeyama K, Nagashima $\mathrm{T}$, Aizawa D, Sugino $\mathrm{T}$, Urakami $\mathrm{K}$, Yamaguchi $\mathrm{K}$ and Terashima M: Aberrant expression of Wnt/beta-catenin signaling pathway genes in aggressive malignant gastric gastrointestinal stromal tumors. Eur J Surg Oncol, 2020. PMID: 32147424. DOI: 10.1016/j.ejso.2020.02.036

30 Sun Y, Xu T, Cao YW and Ding XQ: Antitumor effect of mir$27 b-3 p$ on lung cancer cells via targeting FZD7. Eur Rev Med Pharmacol Sci 21(18): 4113-4123, 2017. PMID: 29028088.

31 Sagara N, Toda G, Hirai M, Terada M and Katoh M: Molecular cloning, differential expression, and chromosomal localization of human frizzled-1, frizzled-2, and frizzled-7. Biochem Biophys Res Commun 252(1): 117-122, 1998. PMID: 9813155. DOI: 10.1006/bbrc.1998.9607

32 Travis WD, Brambilla E, Burke AP, Marx A and Nicholson AG: WHO Classification of Tumours of Lung, Pleura, Thymus and Heart (Fourth edition). Lyon, IARC Press, 2015.

33 Travis WD and Brambilla E: WHO Classification of Tumours. Pathology and Genetics of Tumours of the Lung, Pleura, Thymus and Heart. Lyon, IARC Press, 2004.

34 Sobin LH, Gospodarowicz MK and Wittekind C: TNM Classification of Malignant Tumours (seventh edition). WileyBlackwell, 2009.

35 Freiin Grote A, Halske C, Behrens HM, Kruger S, Wilhelm F, Egberts JH and Rocken C: Expression of LGR5, FZD7, TROY, and MIST1 in perioperatively treated gastric carcinomas and correlation with therapy response. Dis Markers 2019: 8154926, 2019. PMID: 31827644 . DOI: $10.1155 / 2019 / 8154926$

36 Li X, Chen H, Liu Z, Ye Z, Gou S and Wang C: Overexpression of MIST1 reverses the epithelial-mesenchymal transition and reduces the tumorigenicity of pancreatic cancer cells via the SNAIL/E-cadherin pathway. Cancer Lett 431: 96-104, 2018. PMID: 29859299. DOI: 10.1016/j.canlet.2018.05.043

Received September 10, 2020

Revised September 18, 2020

Accepted September 21, 2020 